\title{
On the road to an electric mobility mass market - How can early adopters be characterized?
}

Axel Ensslen, Alexandra-Gwyn Paetz, Sonja Babrowski, Patrick Jochem, Wolf Fichtner

No. 8 | May 2015

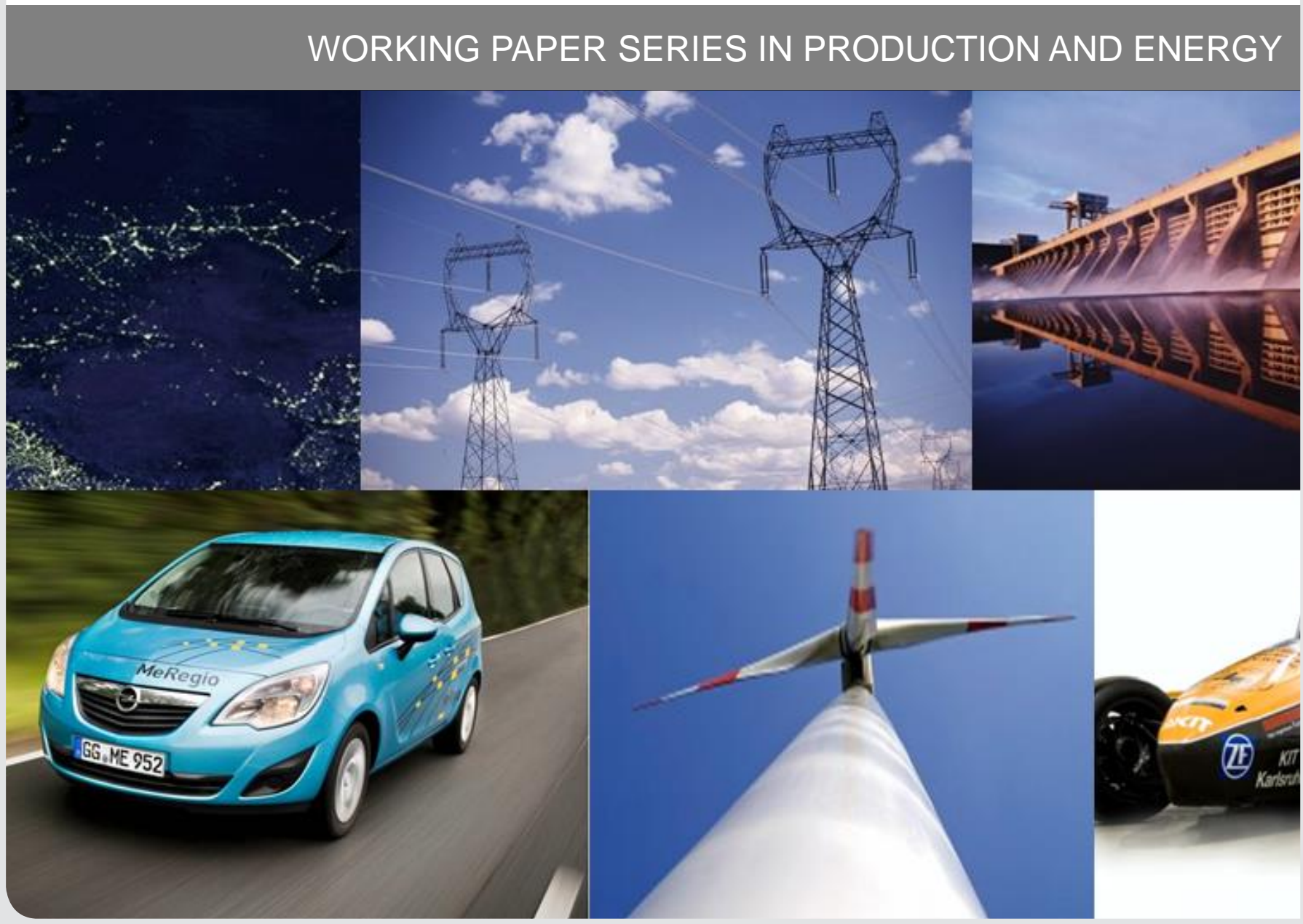




\title{
On the road to an electric mobility mass market - How can early adopters be characterized?
}

\author{
Axel Ensslen*,+49 721 608-44578, axel.ensslen@kit.edu (corresponding author) \\ Alexandra-Gwyn Paetz*,+49 721 608-22002, alexandra-gwyn.paetz@kit.edu \\ Sonja Babrowski*,+49 721 608-44676, sonja.babrowski@kit.edu, \\ Patrick Jochem*, +49 721 608-44590, jochem@kit.edu, \\ Wolf Fichtner*, +49 721 608-44460,wolf.fichtner@kit.edu
}

* Karlsruhe Institute of Technology (KIT), Institute for Industrial Production - Chair of Energy Economics, Hertzstr. 16, 76187 Karlsruhe, Germany

This paper has been prepared for the Workshop "Future Mobility - Markets and policy measures in the evolution of electric mobility“ $5^{\text {th }}$ and $6^{\text {th }}$ December 2013 at OFFIS e.V. in Oldenburg.

Original source of this working paper: Ensslen, A.; Paetz, A.-G.; Babrowski, S.; Jochem, P.; Fichtner, W.: On the road to an electric mobility mass market - How can early adopters be characterized? In: Hülsmann, M. \& Fornahl, D. (Ed.) (o.J.): Markets and policy measures in the evolution of electric mobility. Berlin, Heidelberg: Springer (forthcoming). Copyright $(c)$ by Springer-Verlag.

\begin{abstract}
Different field trials and corresponding acceptance studies with new technologies have been carried out between 2010 and 2013 at the Chair of Energy Economics at the Karlsruhe Institute of Technology (KIT). Those involved Electric Vehicle (EV) users, Liquefied Petroleum Gas (LPG) and Compressed Natural Gas (CNG) vehicle users as well as persons with strong interest in EV and smart home technologies. In order to characterize early adopters the same item-sets concerning attitudes regarding climate change, prices and innovations as well as corresponding socio-demographic characteristics, were used throughout all these studies and have been joined now and analyzed together. Additionally, regression methods have been applied in order to characterize early EV adopters based on a subsample of EV company car users in the French-German context. A binary logit model explaining private EV purchase intention has been developed. According to this model, early private EV adopters are likely to have a higher level of income, to have a household equipped with two or more cars and to travel more than 50 kilometers a day, not necessarily by car. This model additionally shows that possibilities to experience EV (e.g. by test drives) are important leverages to support adoption of EV by private car buyers. Respondents who already decided to privately purchase an EV show significantly lower general price sensitivities than the LPG and CNG vehicle users.
\end{abstract}


Keywords: Electric Vehicle, Electric Mobility, Early Adopter, User Acceptance, User Experience, EV Diffusion.

\section{Introduction}

The European and German aim of reducing Greenhouse Gas Emissions (GHG) by $80 \%$ by the year 2050 compared to 1990 (European Commission 2011) will cause changes in the transportation sector as today it accounts for about $17 \%$ of the total German GHG emissions (Eurostat 2013a), with a continuously increasing share. As individual road transportation is responsible for the main share of those emissions (Eurostat, 2013a), significant changes seem unavoidable with regard to the share of passenger cars running on alternative fuels (cf. Kay et al. 2013).

Vehicles running on liquefied petroleum gas (LPG), compressed natural gas $(\mathrm{CNG})$, and on electricity $\left(\mathrm{EV}^{1}\right)$ have been discussed as a more energy-efficient and climate-friendly means of individual transportation. Cars running on LPG and CNG have been on the market for several years and 500,867 (LPG) respectively 79,065 (CNG) were on German roads by January 2014 (KBA 2014). Even though those two technologies have the highest share among cars with alternative fuels, LPG and CNG cars account for only about $1 \%$ of the total German passenger car fleet (KBA 2014).

Due to positive developments in the battery technology (Thielmann et al. 2012), battery electric vehicles (BEV) have undertaken a rebirth in the last years. Currently around 40 different EV are offered on the German market (Eckl-Dorna \& Sorge 2013) and 12,156 cars were registered on January $1^{\text {st }}, 2014$ (KBA 2014). Although the market seems dynamic (on a low level), the market stage is somewhat earlier compared to LPG and CNG. At the same time German policy measures are strongly aiming at entering the mass market with EV. Accordingly, the government pronounced the ambitious targets of 1 Million EV in 2020 and 6 Million EV in 2030 (BMVBS 2011). Assuming that the German passenger car fleet remains constant, that means that about $2.5 \%$ respectively $15 \%$ of the passenger cars would be substituted with EV. Even though policy measures have predominantly been targeting to technology developments that are supportive to the supply side of four-wheeled EV (cf. Bundesregierung 2009), a strong market penetration of electric two-wheelers can already be observed. Over one million pedal electric cycles (pedelecs) and electric scooters (e-scooters) are already on German roads (Dütschke et al. 2013).

Policy measures are needed in order to extend the success of electric drives from pedelecs and e-scooters to passenger cars capable of being charged in a smart way.

\footnotetext{
${ }^{1} \mathrm{EV}$ is used as synonym for all vehicles including Battery Electric Vehicles or All-Electric Vehicles (BEV), Range Extended Electric Vehicles (REEV) and Plug-in Hybrid Electric Vehicles (PHEV).
} 
But at whom should the measures supportive to EV diffusion target? Who are the first potential buyers of EV and how can they be characterized? Do these early EV adopters resemble early adopters of other technologies, such as LPG/CNG and smart energy home technologies? If so, can we learn from those market experiences?

Smart energy home technologies are particularly focused on as along with higher penetration rates of EV there will be an increasing impact on the electricity system (cf. Jochem et al. 2013). A higher share of EV in the car fleet will increase power demand during peak hours in residential areas considerably, if EV are not charged in a controlled "smart" way. Possible solutions to this challenge could be provided by demand side management solutions, such as automatic delayed EV charging (cf. Jochem et al. 2013). The technical solutions needed to make smart charging possible are based on Information and Communication Technologies (ICT) and discussed as smart technologies, such as charging spots with smart meters.

In this article early adopters are characterized as individuals who have already been using or are actively interested in innovations and are therefore likely to adopt these innovations when the markets reach early adopter phase. Up to now, this has not been the case for the markets of smart home technologies (cf. Bundesnetzagentur 2011) and EV (cf. Wietschel et al. 2013). The EV market is in a very early phase, i. e. only innovators already took the decision to purchase an EV in Germany. Unlike that, LPG and CNG early adopters already took the purchase decision, as this market is in an advanced position compared to the market of EV and smart home technologies (cf. Dütschke et al. 2011).

In order to characterize innovators and early adopters of EV the authors compare innovators and early adopters from different studies considering their price sensitivities, their environmental awareness as well as their innovativeness. Furthermore, the authors look at early EV adopters' attitudes towards EV and try to identify their willingness to purchase an EV according to their mobility behavior, their experience levels with EV as well as socio-demographic characteristics.

This article has the following structure. A literature review (2) is conducted in order to integrate the studies that have been performed into the current stage of scientific knowledge. Next, the survey subsamples under consideration are presented and characterized by analyzing corresponding environmental awareness, price sensitivities, innovativeness as well as socio-demographic characteristics (3). Furthermore, regression approaches are applied to explain potential willingness to privately purchase an EV within the next years based on fleet EV users' attitudes and norms, their mobility behaviors, their experience levels with EV as well as their socio-demographic backgrounds (4). After a brief summary and conclusion (5) the outlook discusses how one of the models could be applied to the existing representative mobility studies (e.g. $\mathrm{ENTD}^{2}, \mathrm{MiD}^{3}$ ) in order to derive conclusions about EV adoption potentials within the next years in France and Germany (6).

\footnotetext{
${ }^{2}$ Enquête nationale transports et déplacements 2008

${ }^{3}$ Mobilität in Deutschland 2008
} 


\section{Literature review}

\subsection{Theory on diffusion of innovations}

According to Rogers (2003), the diffusion of new products such as EV takes place in several steps depending on the share of customers that adopt the new product over time. In the first stage, so called innovators try these new products as soon as they are offered on the market. They usually make up for about $2.5 \%$ of the population. Assuming that all vehicles on German roads (43.9 Million, cf. KBA 2014a) would be replaced with EV, the main users of somewhat more than one million EV would all be called innovators. Afterwards early adopters follow $(13.5 \%)$. Then the early and late majority (34\% each) and at last the so called laggards $(16 \%)$ who are not really interested in new products follow.

As adoption can be described as decision making process of individuals to finally accept an innovation, using stated preference survey data in order to identify the early adopters of an innovation seems appropriate (cf. Bass 2004)

\subsection{Characterizing early EV adopters based on stated preference survey data}

Wietschel et al. (2012) identify early adopters of EV in Germany until 2020 on the basis of surveys and group discussions with EV users focusing on their economic, attitudinal and socio-demographic backgrounds. They indicate that the probability of privately purchasing an EV among current users is highest for men in the beginning of their $40 \mathrm{~s}$, with a higher socio-economic status and most likely having a technical profession. This potential customer group is likely to live in multiperson households with several vehicles, which tend to be in rural areas or in the outskirts. However, selling EV only to this group will not be sufficient in order to target one million EV until 2020. According to Wietschel et al. (2012) about 50,000 vehicles could be sold to this group annually. About 80,000 vehicles would be needed to be sold annually to private customers to reach the German goal of one million EV. In order to derive conclusions about the diffusion process Wietschel et al. (2013) characterize innovators as EV users $(0.5 \%$ of the population), early adopters as individuals interested in EV with purchase intention ( $1 \%$ of the population) and the early majority as individuals without purchase intention but interested in EV ( $48 \%$ of the population). The remaining share of the population are identified as laggards and as such not interested in EV today.

Hackbarth \& Madlener (2013) conduct a discrete choice analysis based on survey data they collected in Germany. They applied a mixed logit model in order to derive conclusions about potential demand for Alternative Fuel Vehicles (AFV) in Germany, particularly for plug-in cars. Results indicate that relatively young, 
well-educated and environmentally-aware survey participants who have the possibility to plug in their car at home and undertake numerous urban trips are most sensitive to AFV adoption. Opposing the findings of Mabit \& Fosgerau (2011) and Ziegler (2012) the model of Hackbarth \& Madlener (2013) explaining EV purchase intention does not observe significant influences of the variables gender, number of children and number of cars in the household.

Glerum et al. (2013) forecast EV demand by accounting for attitudes and perceptions. Their analyses are based on stated preference surveys with personalized choice situations involving conventional cars and EV. Swiss survey participants have been interviewed at the beginning of 2011. They characterize target EV customers as public transportation users living in households owning several cars, with high incomes and rather young. Furthermore, they find that the introduction of a large incentive (5,000 CHF) on the purchase price of an EV can promote its choice, whereas too-high operating costs $(5.40 \mathrm{CHF} / 100 \mathrm{~km})$ can discourage it.

Ensslen et al. (2012) point out that a quite high number of EV users participating in the fleet test CROME could envision purchasing an EV within the next ten years. Less than $20 \%$ stated not to be willing to do so, about $35 \%$ stated being willing to do so and about $45 \%$ of the respondents were undecided. According to Ensslen et al. (2013a) potential early EV adopters are likely to live in rather rural French areas due to favorable total cost of ownership (TCO), a relaxed parking situation in small municipalities and a high average number of cars per household, which compensates for the range-specific disadvantages most EV have. Annual car mileage is on average higher for people living in small municipalities, which makes TCO favorable. Additionally, French adopters benefit from EV purchase incentives. By the time the survey took place a bonus of 7,000 Euros has been provided by the French government. Furthermore, French adopters benefit from comparably lower electricity costs (cf. Eurostat 2013b) which additionally improves TCO calculations for French EV adopters. After the EV users have been experiencing the EV for about a year, user acceptance has been studied with a second survey. Ensslen et al. (2013b) analyze BEV users' attitudes and norms potentially influencing BEV purchase decisions in the French-German context. The authors stress that French BEV users are more concerned about climate change than their German counterparts. Furthermore, their results show, that the French respondents indicate a higher innovativeness level. On the other hand the German respondents indicate to a higher degree that having BEV as company cars has a positive external communication effect. Also, highly significant differences can be observed concerning the French and German BEV users' degrees of satisfaction with the BEVs' $\mathrm{CO}_{2}$ emission characteristics. Although Wietschel et al. (2012) as well as Ensslen et al. (2013a) point out BEVs' advantages in less urbanized areas (due to an easy access to charging possibilities at home and better TCO values), users living in rather urban municipalities indicate higher degrees of satisfaction with different characteristics of $\mathrm{BEV}$ (e.g. low $\mathrm{CO}_{2}$ emissions, sufficient range) (cf. Ensslen et al. 2013b).

Peters et al. (2011a) describe that energy-relevant purchase decisions of consumers for a passenger car can to a large extent be explained by psychological 
factors like attitudes towards more fuel-saving vehicles and awareness of problems related to fuel consumption. Therefore, Peters et al. (2011a) extended Rogers' theoretical framework specifically for EVs and determined an additional dimension called social norm influencing the EV adoption process. Peters et al. (2011b, 2013) base their theoretical framework explaining households' purchase decisions of fuel efficient vehicles in Switzerland on a theoretical model of Bamberg and Möser (2007) which includes psychological factors including social and personal norms, problem awareness and perceived behavioural control.

Dütschke et al. (2011) derive conclusions about policy measures supportive to EV diffusion on survey data received from LPG and CNG adopters collected in the end of the year 2010 from individuals who indeed purchased a LPG or CNG car. According to their results, motives to purchase LPG and CNG cars are rather not likely being linked to an innovative technology. Economic aspects are most important, followed by ecological aspects. Accordingly EVs have a decisive advantage as they have the image to be environmentally friendly. At the point of time of the survey a big disadvantage of EV were their comparably high purchase prices. According to the survey participants information concerning LPG and CNG cars has preferably been collected by talking to other users during the decision making process. Dütschke et al. (2011) conclude that strategies like field trials could be supportive for EV diffusion, as they could be contributive to a better perception of the reliability and safety of the EV technology. Several other studies are supportive to the field trial strategy, too, as they mention positive reactions of individuals who have tested and used EV (cf. Peters \& Dütschke 2010, Peters \& Hoffmann 2011). Peters et al. (2011) recommend providing lowthreshold opportunities to test EV to consumers, especially for marketing campaigns and promotional measures, as EVs' driving characteristics are often perceived as very positive.

\subsection{Identification of EV adopters in representative datasets}

The early adopters in representative mobility studies are mostly identified by rational choice decisions such as TCO. Emotional and maybe "irrational" reasons for buying an EV are neglected. This subchapter provides a brief overview on studies identifying early EV adopters in representative studies based on rational choice.

Mendes Lopes et al. (2014) identify the households to whom limited range BEV would be a plausible choice based on a rule-based screening methodology. Households in the Lisbon Metropolitan Area in Portugal have been classified according to a set of indicators (e.g. home location, daily trips). Five profiles have been defined which correspond to an increasing probability of including BEV in their choice set. According to their results, BEV are only suitable for $1.8 \%$ of the households in the Lisbon Metropolitan Area. Existence of financial incentives would increase the share of EV qualifying households to $6.2 \%$. However, even if prices would not be a barrier, BEV would only be suitable to $10.4 \%$ of the 
households under consideration. According to their analyses, households with more cars, a higher household income, with adequate parking space and a travelling distance that fits to the limited range of BEV qualify for BEV.

Windisch (2013) conducted an analysis on the effectiveness of monetary demandside policy measures (e.g. purchase primes) on EV diffusion of privately held vehicles. The author chose a disaggregate approach based on the database of the French National Transport Survey 2007/2008. Results of TCO calculations show that $\mathrm{EV}, \mathrm{BEV}$ in particular, can be financially interesting to private customers under certain conditions. Furthermore, her results show that long-electric-range PHEV do not appear to be a financially viable alternative under any realistic vehicle usage assumptions. Her results show that around 35\% of the French households are adapted to the needs and limitations of a BEV, i.e. motorized households with access to parking infrastructure where recharge infrastructure could be installed and with vehicle usage behavior not being constrained by BEVs' limited range. Furthermore, her results show that $51 \%$ of the French households are compatible with a PHEV, i.e. motorized households with access to parking infrastructure that can be equipped with a battery recharging infrastructure. Her results even indicate that the need for private parking infrastructure is a more limiting factor to potential EV uptake than compatible EV usage behavior. Concerning the TCO calculations, her results show high sensitivities concerning EV qualifying households according to the purchase primes granted by the government. Under a 5,000 Euro purchase bonus buying a $\mathrm{BEV}$ is only rational for $3.5 \%$ of the French households. A 7,000 Euro purchase bonus on the other hand makes it rational for about $28.2 \%$ of the households to purchase a BEV. Her results show that in rather rural areas (Petite and Grande Couronne) a lot of the household are practically compatible with BEVs' needs according to their driving patterns $(17.3 \%$ and $31.4 \%)$. However, considering the TCO only $1.4 \%$ respectively $3.0 \%$ of the households in the Petite respectively the Grande Couronne area are EV qualified. In the urban center (Paris) on the other hand only $6.9 \%$ of the households are practically compatible with BEVs. However, all of these household would also qualify for BEV from a TCO point of view when preferential parking tariffs for EVs would be introduced in urban centers. Furthermore, the ongoing decreasing battery price would lead to lower required purchase bonus payments as of today.

Wietschel et al. (2013) also base their analysis concerning EV diffusion in Germany on TCO calculations. For private and official car users their analysis was based on data from the German Mobility Panel (MOP 2012), additionally they also consider operational driving profiles of company fleet vehicles (cf. Fraunhofer ISI 2012). Overall 6,500 driving profiles formed the basis for their calculations. Framework conditions are described for three scenarios (pro EV, middle, contra EV) including the development of economic parameters (i.e. fuel prices, battery prices and electricity prices). TCO calculations can be performed considering infrastructure costs, limited supply of adequate EV models as well as increased willingness to pay for an EV. Their results show that depending on the scenario settings EV stock in Germany in 2020 varies between 50,000 and $1,400,000$. Their results also indicate that the $\mathrm{EV}$ diffusion is sensitive to 
monetary demand side policy measures (purchase bonus payments up to 2,000 Euros). EV stock could be almost doubled until 2020 with a purchase prime of only 1,000 Euros. Main profiteer would be commercial fleets who would make up for almost $60 \%$ of market growth.

Based on a TCO model Pfahl et al. (2013) show that only half of the targeted 1 million EV can be expected by 2020 in Germany without subsidies. They also find that small changes of parameters (e.g. increase of oil price, decrease of battery costs, etc.) can lead to significant higher numbers of EV on the German car market.

\section{Characterization of early adopters}

\subsection{Data used}

In order to gain more information about possible early EV adopters and therefore about the possible diffusion process of EV, the authors have evaluated several studies that were conducted at KIT's chair of Energy Economics in the years 2010 - 2013 focusing on the attitudes of the study participants. This was possible, as a set of several items concerning beliefs and attitudes was used throughout all studies using Roger's theory of diffusion of innovations as conceptual framework (Rogers 2003). The participants differ with regard to their prior experiences and their stage of adoption with the technologies under study: no prior experience (interested, but no adoption), regular users (adoption, but no buying decision), adopters (real buying decision).

The authors have analysed the following different technologies: LPG and CNG vehicles, BEV, as well as smart home technologies. Or more precisely, the following six subgroups have been considered (cf. Table 3.1): (1) private LPG and CNG vehicle users with prior experience and with already accomplished buying decision, (2) survey participants interested in smart home technologies, (3) e-scooter users with prior experiences, (4) private EV users with (only) prior experience and already accomplished buying decision, (5) EV company car users with prior experiences, as well as (6) survey participants interested in EV predominantly not having experienced EV. The different groups are briefly characterized among others by their socio-demographic backgrounds. 
Table 3.1 Overview of the different subgroups within the sample considered in this article

\begin{tabular}{|c|c|c|c|c|c|c|c|}
\hline & & \multicolumn{3}{|c|}{ Subsamples considered } & \multirow[b]{2}{*}{ (4) } & \multirow[b]{2}{*}{ (5) } & \multirow[b]{2}{*}{ (6) } \\
\hline & & (1) & (2) & (3) & & & \\
\hline & & $\begin{array}{l}\text { LPG } \\
\text { and } \\
\text { CNG } \\
\text { vehi- } \\
\text { cle } \\
\text { users }\end{array}$ & $\begin{array}{l}\text { Inter- } \\
\text { ested } \\
\text { in } \\
\text { smart } \\
\text { home } \\
\text { techno- } \\
\text { logies }\end{array}$ & $\begin{array}{l}\text { E- } \\
\text { scooter } \\
\text { users }\end{array}$ & $\begin{array}{l}\text { Private } \\
\text { EV } \\
\text { custo- } \\
\text { mers }\end{array}$ & $\begin{array}{l}\text { EV } \\
\text { com- } \\
\text { pany } \\
\text { car us- } \\
\text { ers }\end{array}$ & $\begin{array}{l}\text { Per- } \\
\text { sons in- } \\
\text { terest- } \\
\text { ed in } \\
\text { EV }\end{array}$ \\
\hline \multirow{2}{*}{\multicolumn{2}{|c|}{ Total of respondents $(n=756)$}} & 130 & 284 & 21 & 17 & 171 & 133 \\
\hline & & Dec. & June & $\begin{array}{l}\text { July } \\
2012 \text { \& } \\
\text { July }\end{array}$ & $\begin{array}{l}\text { Jan. - } \\
\text { Sep. }\end{array}$ & $\begin{array}{l}\text { Sep. } \\
2012 \text { - } \\
\text { May }\end{array}$ & $\begin{array}{l}\text { Dec. } \\
2012 \text { - } \\
\text { Feb. }\end{array}$ \\
\hline Survey period & & 2010 & 2012 & & & & \\
\hline Prior experience & & $\mathrm{x}$ & & $\mathrm{x}$ & $\mathrm{x}$ & $\mathrm{x}$ & \\
\hline Purchase decision & & $\mathrm{x}$ & & & $\mathrm{x}$ & & \\
\hline Age & $\mathrm{n}$ & 119 & 0 & 11 & 16 & 133 & 133 \\
\hline Arithmetic average & & 43 & n.a. & 23 & 38 & 44 & 37 \\
\hline Gender & $\mathrm{n}$ & 120 & 284 & 0 & 13 & 131 & 128 \\
\hline Female & & $5 \%$ & $29 \%$ & n.a. & $15 \%$ & $28 \%$ & $30 \%$ \\
\hline Male & & $95 \%$ & $71 \%$ & n.a. & $85 \%$ & $72 \%$ & $70 \%$ \\
\hline Level of education & $\mathrm{n}$ & 120 & 284 & 21 & 15 & 153 & 132 \\
\hline $\mathrm{PhD} /$ Habilitation & & $3 \%$ & $3 \%$ & $0 \%$ & $33 \%$ & $1 \%$ & $1 \%$ \\
\hline Final degree & & $43 \%$ & $55 \%$ & $0 \%$ & $47 \%$ & $63 \%$ & $51 \%$ \\
\hline Vocational education & & $40 \%$ & $10 \%$ & $0 \%$ & $13 \%$ & $14 \%$ & $16 \%$ \\
\hline $\begin{array}{l}\text { High School degree at university } \\
\text { entrance level }\end{array}$ & & $0 \%$ & $28 \%$ & $100 \%$ & $7 \%$ & $13 \%$ & $17 \%$ \\
\hline (General) CSE & & $11 \%$ & $2 \%$ & $0 \%$ & $0 \%$ & $8 \%$ & $12 \%$ \\
\hline No formal certificate & & $1 \%$ & $1 \%$ & $0 \%$ & $0 \%$ & $0 \%$ & $0 \%$ \\
\hline Other & & $2 \%$ & $1 \%$ & $0 \%$ & $0 \%$ & $1 \%$ & $3 \%$ \\
\hline Monthly net household income & $\mathrm{n}$ & 104 & 218 & 0 & 14 & 79 & 95 \\
\hline$<1.000$ EUR & & $0 \%$ & $11 \%$ & n.a. & $0 \%$ & $0 \%$ & $6 \%$ \\
\hline 1,000 - 1,999 EUR & & $11 \%$ & $26 \%$ & n.a. & $22 \%$ & $10 \%$ & $10 \%$ \\
\hline 2,000 - 2,999 EUR & & $33 \%$ & $20 \%$ & n.a. & $14 \%$ & $22 \%$ & $27 \%$ \\
\hline 3,000 - 3,999 EUR & & $31 \%$ & $16 \%$ & n.a. & $0 \%$ & $32 \%$ & $18 \%$ \\
\hline 4,000 - 4,999 EUR & & $11 \%$ & $14 \%$ & n.a. & $14 \%$ & $21 \%$ & $10 \%$ \\
\hline 5,000 - 5,999 EUR & & $11 \%$ & $6 \%$ & n.a. & $7 \%$ & $9 \%$ & $12 \%$ \\
\hline $6,000-7,000$ EUR & & $2 \%$ & $5 \%$ & n.a. & $7 \%$ & $2 \%$ & $5 \%$ \\
\hline$>7,000$ EUR & & $1 \%$ & $2 \%$ & n.a. & $36 \%$ & $4 \%$ & $12 \%$ \\
\hline
\end{tabular}


(1) The respondents grouped in the cluster CNG and LPG vehicle users come from Germany and are about as old as the EV company car users (5). Noticeable is, that $95 \%$ of this group's respondents are male. Their level of education is somewhat lower than the educational level of the EV company car users. Furthermore, the LPG/CNG car users' level of income is somewhat lower than the level of income of the EV company car users. These car drivers not only use their LPG/CNG car on a regular basis, but they have also bought these cars some time ago - they are thus customers that accomplished a real buying decision process. This dataset has also been used by Dütschke et al. (2011).

(2) The persons of our sample interested in smart home technologies are also predominantly male (70\%). Their level of education is comparable to the EV company car users' as the majority has completed their studies. On the other hand less of them have completed vocational education, but more of them have a high school degree at university entrance level. They are comparatively young and are predominantly living in the region of Karlsruhe. Supposedly many master students have participated in this survey, what would also explain the comparably low levels of income despite their final degrees (i.e. the Bachelor degree).

(3) The e-scooter users are a group of KIT students with an average age of 23 years. They have used an e-scooter during a field operational test over the course of five weeks and were selected by application, thus a strong self-selection effect motivating first movers to apply is assumed (cf. Paetz et al. 2012a; Paetz et al. 2013).

(4) The private EV customers originate from the Stuttgart area and can be characterized as real innovators (cf. Rogers, 2003), as they have really adopted the new technology (regular use as well as buying decision). It is noticeable, that $36 \%$ of them have a monthly net household income above 7,000 EUR and their educational level is the highest, as $80 \%$ of them have completed their studies (33\% of them at Phd level). They are comparably young as they are on average 38 years old (cf. Paetz \& Dütschke 2012).

(5) The major part of the respondents in the group of EV company car users are about 44 years old, live in the Upper-Rhine region in Germany or in AlsaceLorraine in France and have a high level of education. The majority has studied and a final degree. Their household incomes are comparably high. All of them have experienced EV for a longer period of time. At the point of time when responses to the online survey have been collected, they have experienced EV on average for about one year within the framework of the CROME project (cf. Ensslen et al. 2013b). This sample has further been increased by a dataset that has been used by Paetz et al. (2012b) including 15 German EV company car users (cf. Paetz \& Dütschke 2012)

(6) The respondents who are interested in EV but predominantly have not had any experiences with $\mathrm{EV}$ at the point of time they have been participating in the survey (77\%), come from Germany, are on average 37 years old, are predominantly male and their level of education is at about the same level as the sample's of the per- 
sons interested in smart home technologies, i.e. most of them have completed their studies. On the other hand their level of income is comparably higher.

\subsection{Methods used}

In order to derive conclusions about the different groups' (cf. Table 3.1) environmental awareness, their price sensitivities as well as their innovativeness a principal component analysis (PCA) is applied. This is a statistical procedure used to discover structures and to convert a set of observations of possibly correlated variables into a set of values of linearly uncorrelated variables. According to each respondent's evaluation of a set of statements (items) measured on a symmetric agree-disagree Likert scale different factors and corresponding individual factor scores are derived (cf. Table a.1 in die appendix and Backhaus et al. 2008). In order to compare resulting factor scores of the different groups' attitude levels, Kruskal-Wallis one-way analysis of variance (Kruskal-Wallis ANOVA) has been used (cf. IBM SPSS Statistics, 2013a; Hartung et al., 2005), as Gaussian distributions cannot be assumed (detailed results of differences between the different groups' respondents' attitudes cf. Table a.2 in the Appendix). KruskalWallis ANOVA permits to determine whether the different groups' mean values for the three factors differ significantly. This is the case for all three factors to a highly significant degree ( $\mathrm{p}<0.001$ for all three factors.). In order to find out which of the subsamples differ from each other, pairwise comparisons have been considered (cf. Dunn, 1964; IBM SPSS Statistics, 2012).

\subsection{Results}

By applying PCA to eight items three factors have been derived. One measures the respondents' environmental awareness, one their innovativeness and one their price sensitivities (cf. Table a.1 in the Appendix and Fig. 3.1-3.3). The quality of this factor analysis is mediocre as the Kaiser-Meyer-Olkin criterion of Sampling Adequacy is 0.631 (cf. Backhaus et al., 2008). In order to determine whether the scales that have been used to measure the three dimensions mentioned before are internally consistent, Cronbach's Alphas have been calculated indicating that the scales measuring the respondents' environmental awareness as well as their innovativeness are indeed interrelated to a sufficiently high degree, whereas internal consistency of the factor price sensitivity is not acceptable. More detailed information about the PCA that has been conducted including Cronbach's Alphas as well as each items' measure of sampling adequacy can be found in Table a. 1 in the Appendix. Furthermore, adjusted significance levels of Kruskal-Wallis ANOVA pairwise comparisons between the factor scores of the different samples can be 
found in Table a.2 in the Appendix. Information on the following boxplot diagrams are available in IBM SPSS Statistics 2013b.

\subsubsection{Environmental awareness}

Concerning different groups' environmental awareness, significant differences can be observed between French and German EV company car users (5) and almost all other user groups (cf. Fig 1 and Table a.2 in the Appendix). Only private EV customers' (4) environmental awareness is not significantly lower than the EV company car users' (5). As about half of the respondents who are considered in group (5) are French, these differences might mainly be explained by the strong influence the French respondents' had. According to Ensslen et al. (2013b) the French $\mathrm{EV}$ users within the CROME project are more worried about climate change than their German counterparts.

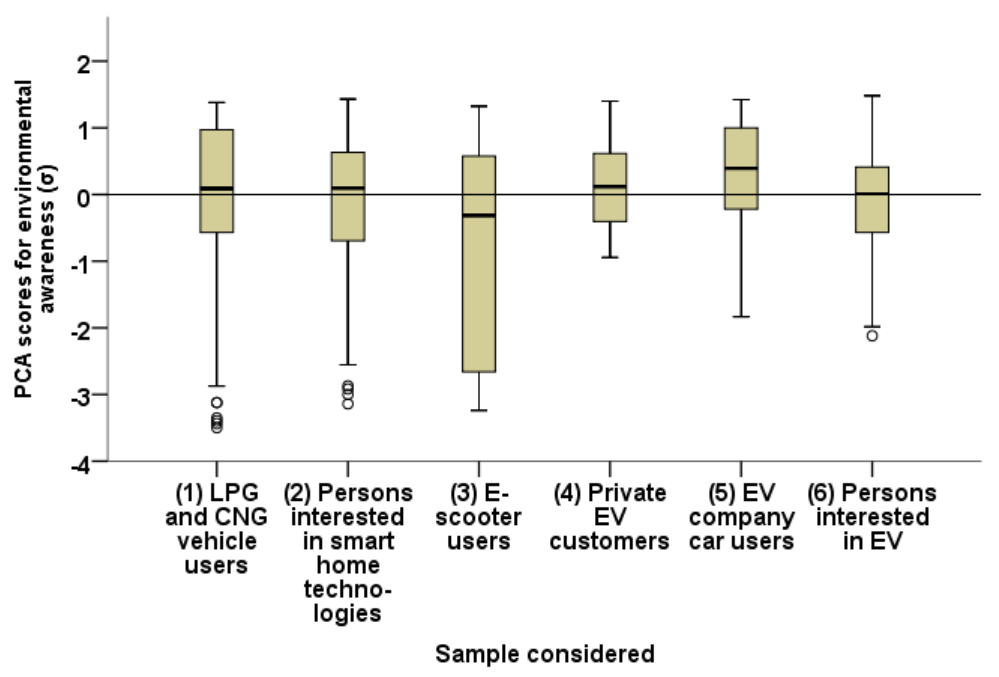

Fig. 3.1 Different samples' respondents' environmental awareness

\subsubsection{Innovativeness}

Innovativeness of private EV customers (4) and CNG/LPG vehicle users (1) as well as of the respondents who are interested in smart home technologies (2) is to a significant degree higher than the innovativeness of those who are interested in EV (6) (cf. Fig. 3.2). Furthermore, innovativeness of respondents who are interested in smart home technologies (2) is significantly higher than innovativeness of respondents who are EV company car users (5). 


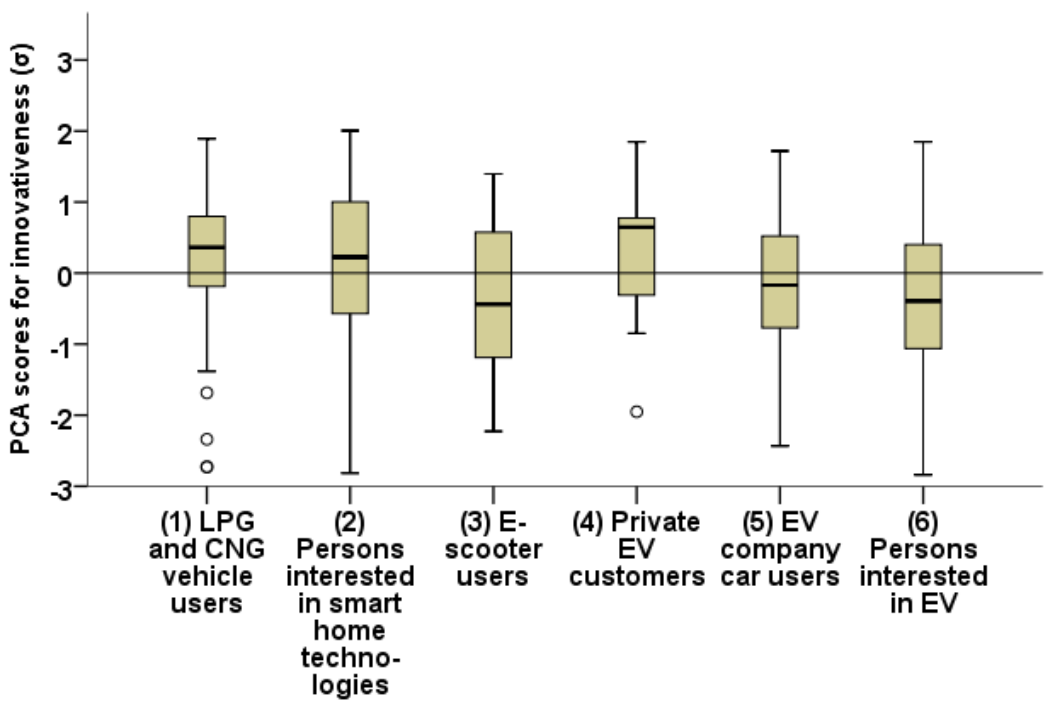

Sample considered

Fig. 3.2 : Different samples’ innovativeness levels

\subsubsection{Price sensitivity}

The sample of e-scooter users (3) is to a significant degree less price sensitive than the sample including persons who are interested in EV (6) and to a highly significant degree less price sensitive compared to the respondents who are interested in smart home technologies (2) and who are LPG and CNG vehicle users (1). As group (3) mainly consists of students this is highly surprising. However, due to the fact, that the usage of e-scooters is in another price range than the other technologies, the comparison might be biased. According to these findings private EV buyers (4) and e-scooter users (3) are least price sensitive. LPG and CNG vehicle users (1) are significantly more price sensitive as well as the respondents who are interested in smart home technologies. Respondents who are interested in EV (6) are to a degree of marginal significance more price sensitive than private EV buyers (4). 


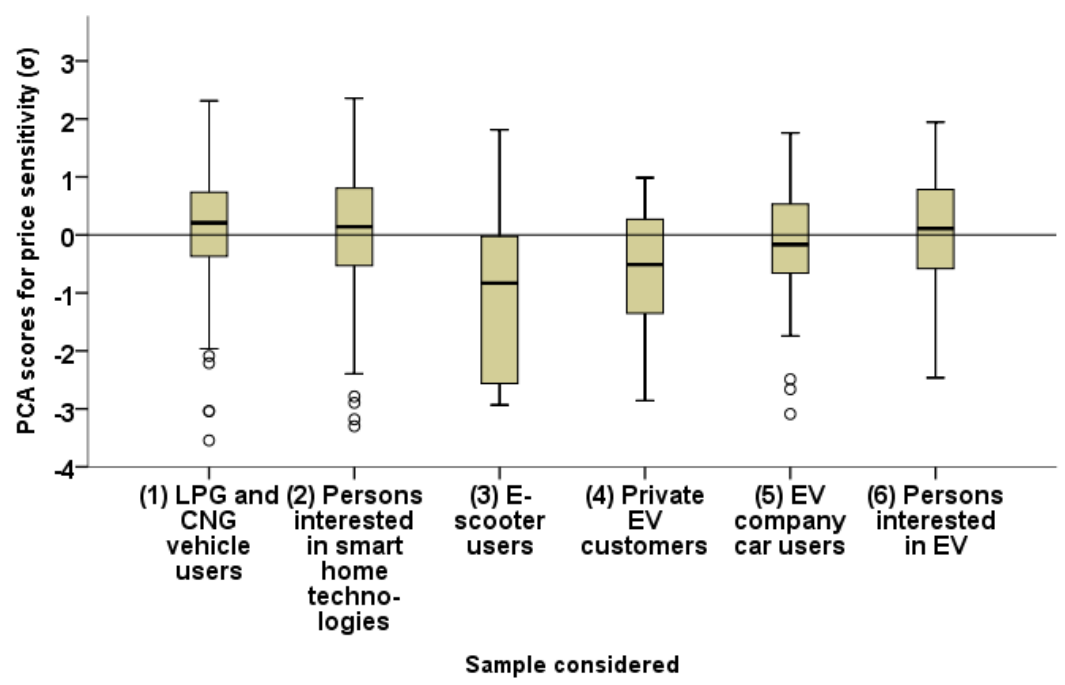

Fig. 3.3 Different groups' price sensitivities

\subsection{Limitations}

Findings concerning price sensitivities of the respondents need indeed to be questioned, as Cronbach's Alpha measuring the internal consistency of the scale which has been designed to measure price sensitivities did not deliver acceptable results. As the different datasets ((1)-(6)) have been collected during different studies, the formulations of underlying questions might partly differ somewhat. Furthermore, the CNG/LPG adopters' evaluations of items concerning the derived three factors (cf. Table a.3 in the Appendix) needed to be transformed from a 7-point scale to a 6-point scale in order to make them comparable with the evaluations in the other datasets. This might bias the results, too.

\section{Intentions of fleet-EV users to privately purchase an EV}

\subsection{Data used}

In order to derive conclusions about BEV users' further adoption intentions characterized by their potential future purchase decision, the dataset of the EV company car users of the CROME project (the major part of the respondents in group 
(5), cf. Table 3.1) has been further analyzed together with data originating from an earlier survey about these EV users' expectations that has been distributed directly after the companies have joined the CROME project. Joining the two datasets has been possible due to the identifying user IDs that have been attributed to the EV users at the beginning of the field test (cf. Ensslen et al. 2012 and Ensslen et al. 2013a).

\subsection{Methods used}

First a comparison between the attitudes and norms of the BEV company car users potentially willing to privately purchase an EV and those users who are not / maybe willing to do so has been conducted. Therefore t-Tests, nonparametric MannWhitney-Tests and binary logistic regression have been applied. Furthermore, the highly significant dependencies between the factor attitude towards $E V$ and the users' degree of satisfaction with different characteristics of the EV have been analyzed and explained by applying linear regression analysis.

Additionally binary logistic regression analysis has been performed in order to develop a model representing EV purchase intention by considering respondents' socio-demographic backgrounds, mobility patterns and their EV experience levels.

\subsection{Results}

\subsubsection{Attitudes and norms influencing EV purchase intentions}

Ensslen et al. (2013b) derived five factors potentially important for individuals' EV purchase intention by applying principal component analysis. The five factors under consideration are the individuals' innovativeness, price sensitivity, environmental awareness, attitude towards $E V$ as well as the perceived external image effect of $E V$.

According to these findings intentions to privately purchase EV within the next years can neither be explained by respondents' environmental awareness nor by their price sensitivity (Fig. 4.4). According to t-Test results, respondents' innovativeness on the other hand discriminates at a marginally significant level between respondents who could envision purchasing an EV within the next years and those who cannot or are undecided. Furthermore, the factors Perceived external image effect of EV and Attitude towards EV discriminate between the two groups at a (highly) significant level. The users' Perceived external image effect of EV has been measured by four items. Attitude towards $E V$ has also been measured by four 
items. This factor is composed of items measuring EVs' relative advantage (i) ("I prefer driving an electric car to driving a conventional car." and "The electric car excites me."), their compatibility with personal attitudes, needs and experiences (ii) ("The electric car is useful in everyday life.") as well as their simplicity of use (iii) ("Using the EV is easy."). According to Rogers (2003) these characteristics of innovations are crucial for individuals' decisions to adopt or to reject an innovation. The factors innovativeness as well as Perceived external image effect of EV further characterize EVs' compatibility (ii) with personal values as well as their compatibility with individuals' perceived social values and norms.

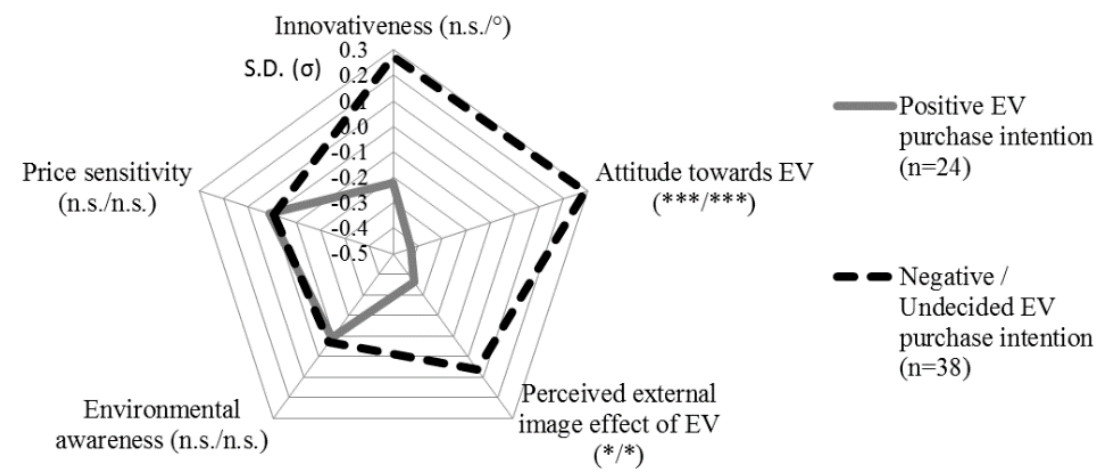

Fig. 4.1 Arithmetic averages of PCA scores (second CROME survey, cf. Ensslen et al. 2013b) according to respondents' answers concerning their intention to purchase an EV within the next years (first CROME survey, cf. Ensslen et al. 2012) ${ }^{4}$

EVs' innovation characteristics trialability (iv) and observability (v) are preconditions within the CROME project, as all of the respondents have the possibility to drive the EV as the EV are part of their companies' fleets. Only at the beginning of the CROME field trial not all of the participants have already used an EV (cf. Ensslen et al. 2013a), so importance of trialability could have been analyzed. Detailed information about the methods and items used to measure (i) - (iii) as well as national factor scores for France and Germany can be found in Ensslen et al. (2013b).

\footnotetext{
${ }^{4}$ Statistical Tests: (Mann-Whitney-Test $/$ T-Test): $\left({ }^{\circ}{ }^{\circ}\right): \mathrm{p}<0.1,(* / *): \mathrm{p}<0.05,(* * / * *): \mathrm{p}<0.01$, $(* * * / * * *): \mathrm{p}<0.001$, (n.s./n.s.): not significant.
}

Original scale: Items have been measured on the following scale: 1: Strongly agree, 2: Agree, 3 : Agree somewhat, 4: Rather disagree, 5: Disagree, 6: Strongly disagree. 


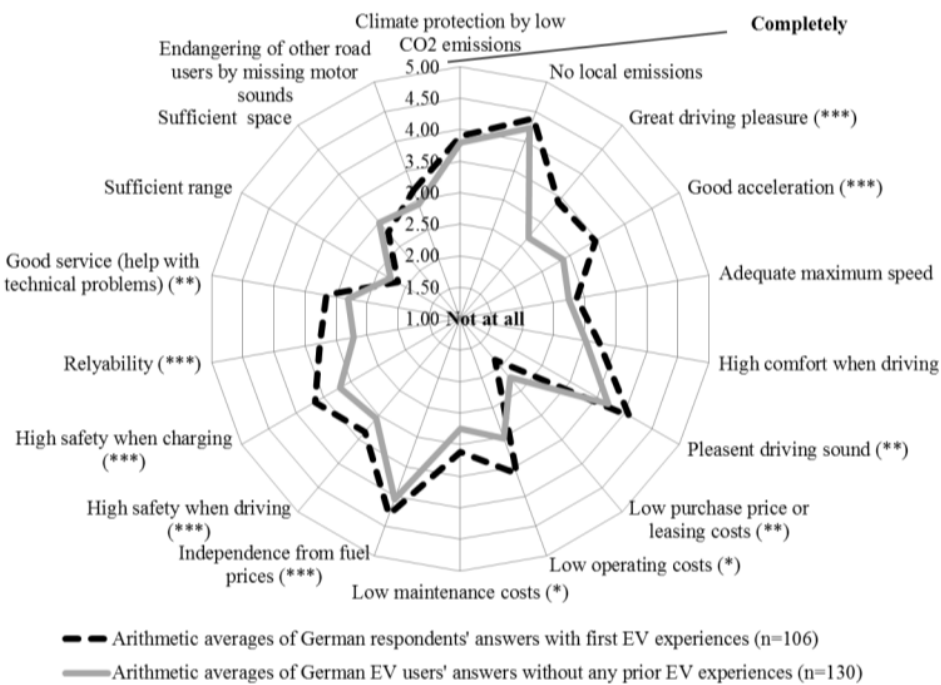

Fig. 4.2 Arithmetic averages of respondents' evaluations about the degree to which they think that the EV will meet their expectations ${ }^{5}$

In the beginning of the field trial participants have been asked about their expectations concerning EV. As about $80 \%$ of the respondents (cf. group (5), Table 3.1) had already experienced the EV when the survey about their expectations has been distributed, the data has additionally been collected from a control sample of respondents interested in BEV (cf. group (6), Table 3.1). Respondents have been asked to which degree they think that different characteristics of EV will meet their expectations. The total sample has been divided into two subgroups. The subgroup which has not experienced EV at all and the subgroup that has experienced EV during at least one or two rides as driver or passenger. Results show that expectations of those who have never tried an EV before have been lower, particularly concerning EVs' driving characteristics, safety and reliability aspects as well as aspects covering operating costs of EV (cf. Fig. 4.5). Respondents with some experiences with EV are for example more likely to evaluate the driving pleasure and the acceleration of EV better than respondents without any experience.

In order to explain the relations between EV users' attitudes and norms and their private EV purchase intention $P_{a}(y=1)$ within the next years, binary logistic regression analyses with the three (marginally) significant factors attitude towards $\mathrm{EV}$, perceived external image effect of EV and innovativeness has been conducted (cf. Fig. 4.4, equations 4.1 and 4.2). Detailed information about the way these dimensions have been measured can be found in Ensslen et al. (2013b).

\footnotetext{
${ }^{5}$ Mann-Whitney-Test results: ${ }^{\circ}: \mathrm{p}<0.1, *: \mathrm{p}<0.05, * *: \mathrm{p}<0.01, * * *: \mathrm{p}<0.001$, n.s.: not significant. Original scale: 1 : Not at all ... 5: Completely.
} 


$$
P_{a}(y=1)=\frac{1}{1+e^{-\beta_{k}}}
$$

with

$$
\beta_{k}=0.786^{*}+1.560 x_{a 1}{ }^{* *}+0.684 x_{a 2}+0.555 x_{a 3}{ }^{\circ}
$$

Description of the variables:

$y$ : Dependent variable representing potential EV purchase intention within the next years ( 0 : Negative or Undecided / 1: Positive)

$x_{a 1}$ : Individuals' PCA score for attitude towards EV

$x_{a 2}$ : Individuals' PCA score for perceived external image effect of EV

$x_{a 3}$ : Individuals' PCA score for innovativeness

$x_{a 1}, x_{a 2}$ and $x_{a 3}$ are provided in standard deviations $(\sigma)$. Details on quality criterions of this regression can be found in Table 4.1. Details on this binary logistic regression in Table a. 4 in the Appendix.

As attitude towards EV $\left(\mathrm{x}_{\mathrm{a} 1}\right)$ highly impacts individuals' purchase intentions and high correlations between EV users' degree of satisfaction with different characteristics of EV and $\mathrm{x}_{\mathrm{a} 1}$ could be observed (cf. Ensslen et al. 2013b), these dependencies have been further analyzed. Therefore linear regression has been performed. The independent variables in the following equation can explain more than half of the variation $\left(n=116 ; R^{2}=0.536\right.$; Adjusted $\left.R^{2}=0.506\right)$ of $x_{a 1}$.

$x_{a 1}=-2.269^{* * *}+0.891 \mathrm{x}_{\mathrm{b} 1}{ }^{* * *}+0.572 \mathrm{x}_{\mathrm{b} 2}{ }^{* * *}+0.357 \mathrm{x}_{\mathrm{b} 3}{ }^{* *}-0.480 \mathrm{x}_{\mathrm{b} 4}{ }^{* *}+$

$0.326 \mathrm{x}_{\mathrm{b} 5}{ }^{*}-0.363 \mathrm{x}_{\mathrm{b} 6}{ }^{*}$

$\mathrm{x}_{\mathrm{a} 1}$ : Attitude towards EV $(\sigma)$

$\mathrm{x}_{\mathrm{b} 1}$ : Great driving pleasure

$\mathrm{x}_{\mathrm{b} 2}$ : General satisfaction with EV

$\mathrm{x}_{\mathrm{b} 3}$ : Safety of other road users when approaching noiseless

$\mathrm{x}_{\mathrm{b} 4}$ : High safety when driving

$\mathrm{x}_{\mathrm{b} 5}$ : High comfort when driving

$\mathrm{x}_{\mathrm{b} 6}$ : Climate protection by low $\mathrm{CO}_{2}$ emissions

$\mathrm{x}_{\mathrm{b} 1}-\mathrm{x}_{\mathrm{b} 6}$ have been measured on the following scale: (1) Not satisfied at all (2) Rather not satisfied (3) Rather satisfied (4) Completely satisfied.

$\mathrm{x}_{\mathrm{a} 1}$ represents PCA scores provided in standard deviations $(\sigma)$.

\footnotetext{
${ }^{6}$ Significance level of Wald statistic: ${ }^{\circ}: \mathrm{p}<0.1 ; *: \mathrm{p}<0.05 ; * *: \mathrm{p}<0.01 ; * * *: \mathrm{p}<0.001$.

${ }^{7}$ Significance level of t-test and Wald statistic: ${ }^{\circ}: \mathrm{p}<0.1 ; *: \mathrm{p}<0.05 ; * *: \mathrm{p}<0.01 ; * * *: \mathrm{p}<0.001$.
} 
Negative correlations between the attitude towards EV $\left(\mathrm{x}_{\mathrm{a} 1}\right)$ and the degrees of satisfaction with EVs' characteristics can be observed concerning climate protection by low $\mathrm{CO}_{2}$ emissions $\left(\mathrm{x}_{\mathrm{b} 6}\right)$ as well as high safety when driving $\left(\mathrm{x}_{\mathrm{b} 5}\right)$. On the other hand $\mathrm{x}_{\mathrm{a} 1}$ is positively correlated with individuals' degree of satisfaction concerning driving pleasure, the general satisfaction level with the EV, individuals' evaluations concerning safety of other road users when approaching noiseless and their indications concerning comfort level.

\subsubsection{Explaining EV purchase intention with EV users' experience levels, income, nationality and mobility needs}

The following equation describes dependencies between individuals' intentions to purchase an EV within the next years and their mobility behaviors, their experience levels with EV, the number of cars in their households, their nationality, their income levels as well as their professional background as fleet manager (cf. equations 4.4 and 4.5 ).

$$
P_{c}(y=1)=\frac{1}{1+e^{-z_{k}}}
$$

with

$z_{k}=-1.567^{*}+0.691 x_{c 1}{ }^{\circ}+2.079 x_{c 2}{ }^{*}-0.349 x_{c 3}-0.970 x_{c 4}{ }^{*}-0.706 x_{c 5}+$

$0.600 x_{c 6}+0.097 x_{c 7}+2.062 x_{c 8}{ }^{* *}+0.649 x_{c 9}+0.587 x_{c 10}{ }^{*}$

Description of the variables:

$y$ : Dependent variable representing potential EV purchase intention within the next years (0: Negative or Undecided / 1: Positive)

$x_{c 1}$ : Travelled mileage on a (work)day $(0:<50 \mathrm{~km} / 1: \geq 50 \mathrm{~km})$

$x_{c 2}$ : Fleet manager and user (0: No / 1: Yes)

$x_{c 3}$ : Respondent has experienced $\mathrm{EV}$ during one or two trips as a driver or passenger (0: No / 1: Yes)

$x_{c 4}$ : Respondent has not experienced EV so far at all (0: No / 1: Yes)

$x_{c 5}$ : Net household income $<4,000 €(0$ : No / 1: Yes $)$

$x_{c 6}$ : Net household income $\geq 4,000 €(0:$ No / 1 : Yes $)$

$x_{c 7}$ : Car usage frequency: 1-3 days per week (0: No / 1: Yes)

$x_{c 8}$ : Car usage frequency: 1-3 days per month or less (0: No / 1: Yes)

$x_{c 9}$ : French respondent (0: No / 1: Yes)

$x_{c 10}$ : Number of cars in the household (0-4 if $x_{c 10} \leq 4 / 5$ if $\left.x_{c 10}>4\right)$

\footnotetext{
${ }^{8}$ Significance level of Wald statistic: ${ }^{\circ}: \mathrm{p}<0.1 ; *: \mathrm{p}<0.05 ; * *: \mathrm{p}<0.01 ; * * *: \mathrm{p}<0.001$.
}

Please consider the reference categories provided in Table a. 3 
Strong dependencies between the independent variable $x_{c 4}$ describing whether the respondents have not experienced $\mathrm{EV}$ at all so far and the dependent variable EV purchase intention can be observed (the odds ratio $\operatorname{Exp}(B)$ is smallest for this variable). This should be further analyzed as this issue is supportive to the hypothesis that there might be wealthy districts where EV diffusion rates might be comparably higher as soon as some of the residents have adopted EV as innovators. This might be challenging the local distribution grids (Jochem et al. 2013 and Waraich 2013).

\subsubsection{Quality criterions of the the binary logit models}

Table 4.1 Quality criterions of the two binary logit models $\boldsymbol{P}_{\boldsymbol{a}}$ and $\boldsymbol{P}_{\boldsymbol{c}}$ representing potential EV purchase intentions within the next years

\begin{tabular}{|c|c|c|c|c|c|}
\hline Model & $\mathrm{n}$ & $\begin{array}{l}\text { Correctly clas- } \\
\text { sified (in \%) }\end{array}$ & Nagelkerke $\mathrm{R}^{2}$ & $\begin{array}{l}\text { Cox \& Snell } \\
\mathrm{R}^{2}\end{array}$ & $\begin{array}{l}\text { P-value of Hosmer and Lemeshow } \\
\text { Test }\end{array}$ \\
\hline$P_{a}$ & 62 & 75.8 & 0.373 & 0.275 & 0.41 \\
\hline$P_{c}$ & 180 & 68.9 & 0.296 & 0.221 & 0.131 \\
\hline
\end{tabular}

The quality criterions of both binary logit models $P_{a}$ and $P_{c}$ are acceptable as values of Nagelkerke $\mathrm{R}^{2}$ as well as of Cox $\&$ Snell $\mathrm{R}^{2}$ serving as quality measure for the models, are at an acceptable level for both models (cf. Table 4.1, Backhaus et al. 2008). Furthermore, p-values for the Hosmer and Lemeshow Tests which analyzes the differences between the model results and the observed values are both not significant. Nevertheless, it needs to be addressed that uncertainties in all three models are high. Details of the models $P_{a}$ and $P_{c}$ are provided in Tables a.3 and a.4 in the Appendix.

\subsection{Limitations}

The independent variables and $x_{a 2}$ and $x_{c 9}$ did not discriminate significantly between the respondents willing to privately purchase an EV within the next years and those not willing to do so. As these are the only variables in the models which are not significant $\left(p_{x_{a 2}}=0.12\right.$ and $\left.p_{x_{c 8}}=0.12\right)$ and the samples are relatively small $\left(n_{a}=62\right.$ and $\left.n_{c}=180\right)$, the authors assume that the hardly not significant $\mathrm{p}$-values are due to the small samples considered. As the models would not be working without the variables it is important to take them into account, even if they are not significant. Furthermore, it needs to be mentioned that the results might be biased somewhat as the surveys have been completed in French and German languages. 


\section{Summary, conclusions and outlook}

During the last years rather low market penetration rates for EV were observable. So far there are some first movers called innovators who privately purchased EV. Furthermore, there are some companies that purchased EV for their car pools. The users of these EV cannot be described as real innovators, as their companies made the decision to purchase the EV. Nevertheless, these persons are using and experiencing the EV technology. Although this group's innovativeness is comparably low, only one fifth of the respondents answered that they could not envision purchasing an EV within the next ten years (cf. Ensslen et al. 2012). These findings are supportive to the role of trialability for diffusion of innovations (Rogers 2003) and are supportive to Peters et al. (2011) mentioning low-threshold possibilities to test EV in order to increase EV acceptance level. Respondents who had the possibility to experience EV show comparably high levels of satisfaction with different characteristics of EV (cf. Fig. 4.5). This is further supported by analyzing who of the company EV users is rather willing to purchase an EV within the next years. According to the binary logistic regression model presented in this article, that has been estimated based on survey data collected in the beginning of the FrenchGerman field operational test CROME, EV usage experience positively impacts EV purchase intentions. According to this model EV purchase intentions increase with a higher level of income, with a higher number of cars in the household and a daily mileage of more than 50 kilometers not necessarily travelled by car. Furthermore, potential explanations for the fact that experiencing EV positively impacts EV purchase intentions are discussed. According to the results presented in this study EV purchase intentions can to a large part be explained by a factor representing the respondents' attitude towards EV (cf. Ensslen et al. 2013b). This factor can be explained by the users' degree of satisfaction with the EVs' driving characteristics, their satisfaction with EVs' safety characteristics as well as their satisfaction levels with EVs' ability to protect the climate by comparably low $\mathrm{CO}_{2}$ emissions.

We have seen that early EV adopters differ from LPG and CNG users particularly concerning educational level, income and price sensitivity. In order to increase market shares of EV significantly and to reach early adopter stage (more than $2.5 \%$ of cars are EV), EV should not only be targeted at individuals with low price sensitivities and high incomes. Furthermore, EV specific disadvantages compared to internal combustion engine vehicles, notably their comparably high prices and their limited range (cf. Figure 4.5) give rise to the assumption that alternative business models targeting economic and range-specific aspects of EV could be supportive to early-stage EV diffusion. Considering that the battery is the most expensive part of an EV, already existing specific battery leasing options might reduce the initial high invest and so make EV affordable to a higher share of potential customers. As the economic perspective of an EV majorly depends on its vehicle miles travelled due to comparably lower variable costs (e.g. costs for electricity are lower than costs for fuel), business models like e.g. carsharing with EV could be a solution. First attempts to realize these business models can already be 
observed. However, whether they are going to be successful in the long run is unclear so far. Car sharing concepts might reduce the EV specific disadvantages range and purchase price from the users' perspectives significantly.

If policy makers wish to take measures in order to support private EV diffusion at the current market stage, thinking about demand side policy measures targeting monetary and non-monetary aspects could be an option. Non-monetary measures should besides the development of public accessible charging infrastructure including adequate parking space particularly focus on establishing possibilities to experience EV (e.g. test drives, e-car-sharing) as EVs' driving characteristics are exceeding the expectations. Possibilities to experience EV should particularly target opinion leaders within the early EV adopters, notably decision makers in organizations potentially being fleet managers. Furthermore, first stage marketing measures to potential private EV adopters should particularly target households with a high net income, equipped with two or more cars and having a high daily mileage. In order to further support possibilities to experience EV, policy makers could additionally think about providing incentives to make usage-oriented business models like e-car-sharing more attractive for potential operators.

Further analyses are planned in order to derive conclusions about EV users' decision concerning powertrain choice during their next car purchase decision. Furthermore, the question is going to be addressed which services are favorable from the users' perspectives in order to compensate for BEV-specific barriers and how these should look like.

Furthermore, after first analyses have already been conducted, the binary logistic regression model explaining EV purchase intention with EV users' experience levels, income, nationality and mobility needs could be applied to representative mobility studies in France and Germany (MiD, ENTD) in order to equip every individual in these studies with EV purchasing probabilities. Exogenous variables which are not available in these studies are their experience levels with EV. However, it can be assumed that these are currently rather small. Furthermore, the research question can be expressed where EV diffusion will take place first. Will this be the case in rather urban or rather rural areas? The research question where early EV adoption will take place in France and Germany should be focused on, as local bottlenecks in the electric power grids due to electric mobility might occur.

\section{Acknowledgements}

We would like to thank Verena Knödler and Mario Ostwald for their contributions and support concerning data collection and analyses. This research was made possible by the CROME project [ref. no. 01ME12002], the MeRegioMobil project [ref. no. 01ME9005] and the iZEUS project [ref. no. 01ME12013] funded by the German Federal Ministry of Economics and Technology (BMWi). 


\section{Bibliography}

Backhaus, K., Erichson, B., Plinke, W., Weiber, R. (2008). Multivariate Analysemethoden. Heidelberg: Springer.

Bamberg, S., Möser, G. (2007). Twenty years after Hines, Hungerford and Tomera: A new metaanalysis of psycho-social determinants of proenvironmental behaviour. Journal of Environmental Psychology, 27, 14-25.

Bass, F.M. (2004). Comments on „A New Product Growth for Model Consumer Durables The Bass Model“". Management Science 50, 1833-1840.

BMVBS (Bundesministerium für Verkehr, Bau und Stadtentwicklung) (2011). Elektromoblilität - Deutschland als Leitmarkt und Leitanbieter. http://www.bmvi.de/SharedDocs/DE/Publikationen/VerkehrUndMobilitaet/elektromobilitaetdeutschland-als-leitmarkt-und-leitanbieter.pdf? blob=publicationFile. Accessed 6 Mar 2014.

Bundesnetzagentur (2011). „Smart Grid“ und „Smart Market“: Eckpunktepapier der Bundesnetzagentur $\mathrm{zu}$ den Aspekten des sich verändernden Energieversorgungssystems. http://www.bundesnetzagentur.de/SharedDocs/Downloads/DE/Sachgebiete/Energie/Unterneh men_Institutionen/NetzzugangUndMesswesen/SmartGridEckpunktepapier/SmartGridPapierp df.pdf? blob=publicationFile\&v=2\%20. Accessed 6 Mar 2014.

Bundesregierung (2009). Nationaler Entwicklungsplan Elektromobilität der Bundesregierung. http://www.bmbf.de/pubRD/nationaler_entwicklungsplan_elektromobilitaet.pdf. Accessed 6 Mar 2014.

Dütschke, E., Unterländer, M., Wietschel, M. (2012). Variable Stromtarife aus Kundensicht Akzeptanzstudie auf Basis einer Conjoint-Analyse. Working Paper Sustainability and Innovation No. S 1/2012. Fraunhofer Institute for Systems and Innovation Research (ISI). http://www.isi.fraunhofer.de/isi-media/docs/e-x/working-papers-sustainability-andinnovation/WP01-2012_Dynamische-Stromtarife_final_v1.pdf. Accessed 6 Mar 2014.

Dütschke, E., Schneider, U., Peters, A., Paetz, A., Jochem, P., (2011). Moving towards more efficient car use - what can be learnt about consumer acceptance from analysing the cases of LPG and CNG. ECEEE 2011 Summer Study.

Dütschke, E., Schneider, U., \& Peters, A. (2013). Who will use electric vehicles?. Working Paper Sustainability and Innovation No. S 6/2013. Fraunhofer Institute for Systems and Innovation Research (ISI). http://www.isi.fraunhofer.de/isi-media/docs/e-x/working-paperssustainability-and-innovation/WP06-2013_Electric_Vehicles.pdf. Accessed 7 Mar 2014.

Dunn, O. J. (1964). Multiple comparisons using rank sums. Technometrics, 6, 241-252.

Eckl-Dorna, W., Sorge, N.-V. (2013). Elektroauto-Markt wächst exponentiell, nicht linear. Interview with Kagermann, Henning. Manager magazin online 2013, http://www.managermagazin.de/unternehmen/autoindustrie/a-901804.html. Accessed 12 Jul 2013.

Ensslen, A., Babrowski, S., Jochem, P., Fichtner, W. (2012). Existe-il des différences d'acceptation des véhicules électriques entre la France et l'Allemagne? - Premiers résultats de l'analyse scientifique du test de flotte Cross Border Mobility for Electric Vehicles (CROME). Proceedings of the $11^{\text {ème }}$ séminaire francophone est-ouest de socio-économie des transports, Karlsruhe.

Ensslen, A., Jochem, P., Schäuble, J., Babrowski, S., Fichtner, W. (2013a). User acceptance of electric vehicles in the French-German transnational context, in selected proceedings of the 13th WCTR, Rio de Janeiro.

Ensslen, A., Jochem, P., Fichtner, W. (2013b). Experiences of EV Users in the French-German Context, Proceedings of EVS27-Conference, Barcelona, Spain.

Eurostat (2013a). Umwelt und Energie Datenbank. http://epp.eurostat.ec.europa.eu/portal/page/portal/climate_change/data/main_tables. Accessed 18 Sep 2013 
Eurostat (2013b). Energy price statistics, http://epp.eurostat.ec.europa.eu/statistics_explained/index.php/Energy_price_statistics. Accessed on 2013-06-25.

European Commission (2011). A roadmap for moving to a competitive low carbon economy in 2050. http://ec.europa.eu/clima/policies/roadmap/documentation_en.htm. Accessed 03/03/14.

Fraunhofer Institute for Systems and Innovation Research (ISI) (2012). REM2030 Driving Profiles Database V2012.

Glerum, A., Stankovikj, L., Thémans, M., Bierlaire, M. (2013) Forecasting the Demand for Electric Vehicles: Accounting for Attitudes and Perceptions. Transportation Science, Articles in Advance, pp. 1-17.

Hackbarth, A., Madlener, R. (2013). Consumer preferences for alternative fuel vehicles: A discrete choice analysis. Transportation Research Part D: Transport and Environment 25, 5-17.

Hartung, J., Elpelt, B., Klösener, K.-H. (2005). Statistik. München: Oldenbourg.

IBM SPSS Statistics (2013a). Kruskal-Wallis One-Way Analysis of Variance (nonparametric tests algorithms). http://pic.dhe.ibm.com/infocenter/spssstat/v21r0m0/index.jsp?topic=\%2Fcom.ibm.spss.statist ics.help\%2Falg_npar_tests_kruskalwallis.htm. Accessed 18 Sep 2013.

IBM SPSS Statistics (2013b). Beispiel: http://pic.dhe.ibm.com/infocenter/spssstat/v20r0m0/index.jsp?topic=\%2Fcom.ibm.spss.statist ics.help\%2Fgraphboard_creating_examples_boxplot.htm. Accessed 18 Sep 2013.

IBM SPSS Statistics (2012). Post hoc comparisons for the Kruskal-Wallis test. http://www01.ibm.com/support/docview.wss?uid=swg21477370. Accessed 22 Oct 2013.

IEA - International Energy Agency (2012). $\mathrm{CO}_{2}$ emissions from fuel combustion. http://www.iea.org/co2highlights/co2highlights.pdf. Accessed 17 Jun 2013.

Jochem, P.; Kaschub, T. and Fichtner, W. (2013). How to Integrate Electric Vehicles in the Future Energy System?, in: Hülsmann, M and Fornahl, D. (Eds.): Evolutionary Paths Towards the Mobility Patterns of the Future, Springer, Heidelberg, Germany.

KBA - Kraftfahrt-Bundesamt (2014). Jahresbilanz des Fahrzeugbestandes am 1. Januar 2014, http://www.kba.de/cln_031/nn_125398/DE/Statistik/Fahrzeuge/Bestand/2014_b_jahresbila nz.html\#rechts. Accessed 19 Mar 2014.

Kay, D., Hill, N., Newman, D. (2013). Powering Ahead - The future of low-carbon cars and fuels. http://www.theengineer.co.uk/Journals/2013/04/22/i/k/h/powering_ahead-kay_et_alapr2013-embargoed_copy.pdf. Accessed 7 Mar 2014.

Kuckartz, U., Rädiker, S., Rheingans-Heintze, A. (2006). Umweltbewusstsein in Deutschland. Marburg. $\quad$ http://www.umweltbundesamt.de/publikationen/umweltbewusstsein-indeutschland-2006. Accessed 10 Mar 2014.

Lichtenstein, D., Ridgway, N., Netemeyer, R. (1993). Price Perception Scales. In: Bearden, W., Netemeyer, R., Haws, K. (2011). Handbook of Marketing Scales. Thousand Oaks: SAGE Publications.

Mabit, S.L., Fosgerau, M. (2011). Demand for alternative-fuel vehicles when registration taxes are high. Transportation Research D 16, 225-231.

Manning, K., Bearden, W., Madden, T. (1995). Innovativeness: Consumer Innovativeness. In: Bearden, W., Netemeyer, R., Haws, K. (2011). Handbook of Marketing Scales. Thousand Oaks: SAGE Publications.

Mendes Lopes, M., Moura, F., Martinez, L. M. (2014). A rule-based approach for determining the plausible universe of electric vehicle buyers in the Lisbon Metropolitan Area. Transportation Research Part A, 59, 22-36.

MOP (2012). Mobilitätspanel Deutschland (MOP). http://www.clearingstelle-verkehr.de. Accedded 7 Mar 2013.

Paetz, A.-G., Dütschke, E. (2012). Auf dem Weg in die elektromobile Zukunft - Ein Zwischenfazit zur Elektromobilität im Alltag. SIV.news, 1/2012: 45-47.

Paetz, A.-G., Kaschub, T., Jochem, P., Fichtner, W. (2012a). Demand Response with Smart Homes and Electric Scooters: An Experimental Study on User Acceptance. 
http://www.aceee.org/files/proceedings/2012/data/papers/0193-000232.pdf. Accessed 7 Mar 2014.

Paetz, A.-G., Jochem, P., Fichtner, W. (2012b). Demand Side Management mit Elektrofahrzeugen - Ausgestaltungsmöglichkeiten und Kundenakzeptanz. 12th Symposium Energieinnovation, $\quad$ Feb 2012, Graz, Austria http://portal.tugraz.at/portal/page/portal/Files/i4340/eninnov2012/files/lf/LF_Paetz.pdf. Accessed 7 Mar 2014.

Paetz, A.-G., Kaschub, T., Pfriem, M., Jochem, P., Fichtner, W., Gauterin, F. (2013). Is Electric Mobility a Means for more Sustainability?. Behavior, Energy \& Climate Change Conference, Nov 2013, Sacramento.

Parasuraman, A. (2000). The Technology Readiness Index. In: Bearden, W., Netemeyer, R., Haws, K. (2011). Handbook of Marketing Scales. Thousand Oaks: SAGE Publications.

Peters, A., Dütschke, E. (2010). Zur Nutzerakzeptanz von Elektromobilität. Analyse aus Expertensicht. Fraunhofer Institute for Systems and Innovation Research (ISI) http://publica.fraunhofer.de/eprints/urn:nbn:de:0011-n-1450132.pdf. Accessed 7 Mar 2014.

Peters, A., Hoffmann, J. (2011). Nutzerakzeptanz von Elektromobilität. Eine empirische Studie zu attraktiven Nutzungsvarianten, Fahrzeugkonzepten und Geschäftsmodellen aus Sicht potenzieller Nutzer. Fraunhofer Institute for Systems and Innovation Research (ISI). http://isi.fraunhofer.de/isi-

me-

dia/docs/service/de/presseinfos/Forschungsergebnisse Nutzerakzeptanz Elektromobilitaet.pd f. Accessed 7 Mar 2014

Peters, A., Popp, M., Agosti, R., Ryf, B. (2011a). Electric mobility - a survey of different consumer groups in Germany with regard to adoption. ECEEE Summer Study proceedings. http://publica.fraunhofer.de/eprints/urn:nbn:de:0011-n-1834806.pdf. Accessed 7 Mar 2014.

Peters, A., Gutscher, H., Scholz, RW. (2011b). Psychological determinants of fuel consumption of purchased new cars. Transportation Research Part F: Psychology and Behaviour 14:229 239

Peters, A., de Haan, P., Scholz, W. (2013). Understanding Car Buying Behavior: Psychological Determinants of Energy Efficiency and Practical Implications. International Journal of Sustainable Transportation. DOI: 10.1080/15568318.2012.732672.

Pfahl, S. (2013). When Will Electric Vehicles Capture the German Market? And Why?, Proceedings of EVS27-Conference, Barcelona, Spain.

Rogers, E.M. (2003). Diffusion of Innovations. Fifth edition. New York: Free Press.

SINUS (2012). Klimaschutz in Heidelberg. http://www.uniheidelberg.de/md/journal/2013/02/14jan_heidelbergstudie_2012.pdf. Accessed 7 Mar 2014.

Thielmann, A., Sauer, A., Isenmann, R., Wietschel, M., Plötz, P. (2012). Produkt-Roadmap Lithium-Ionen-Batterien 2030. Fraunhofer Institute for Systems and Innovation Research (ISI). http://www.isi.fraunhofer.de/isi-media/docs/v/de/publikationen/PRM-LIB2030.pdf. Accessed 7 Mar 2014.

Waraich, R. A., Galus, M.D., Dobler, C., Balmer, M., Andersson, G., Axhausen, K. W. (2013). Plug-in hybrid electric vehicles and smart grids: Investigations based on a microsimulation. Transportation Research Part C 28, 74-86.

Wietschel, M., Dütschke, E., Funke, S., Peters, A., Plötz, P., Schneider, U. (2012). Kaufpotenzial für Elektrofahrzeuge bei sogenannten „Early Adoptern“. Fraunhofer Institute for Systems and Innovation Research (ISI). http://isi.fraunhofer.de/isimedia/docs/e/de/publikationen/Schlussbericht_Early_Adopter.pdf. Accessed 7 Mar 2014.

Wietschel, M., Plötz, P., Kühn, A., Gnann, T. (2013). Markthochlaufszenarien für Elektrofahrzeuge. Fraunhofer Institute for Systems and Innovation Research (ISI) http://www.isi.fraunhofer.de/isi-media/docs/e/de/publikationen/Fraunhofer-ISIMarkthochlaufszenarien-Elektrofahrzeuge-Langfassung.pdf. Accessed 7 Mar 2014. 
Windisch, E. (2013). Driving electric? A financial assessment of electric vehicle policies in France. Paris.

Ziegler, A. (2012). Individual characteristics and stated preferences for alternative energy sources and propulsion technologies in vehicles: a discrete choice analysis for Germany. Transportation Research A 46, 1372-1385. 


\section{Appendix}

Table a.1 Rotated component matrix

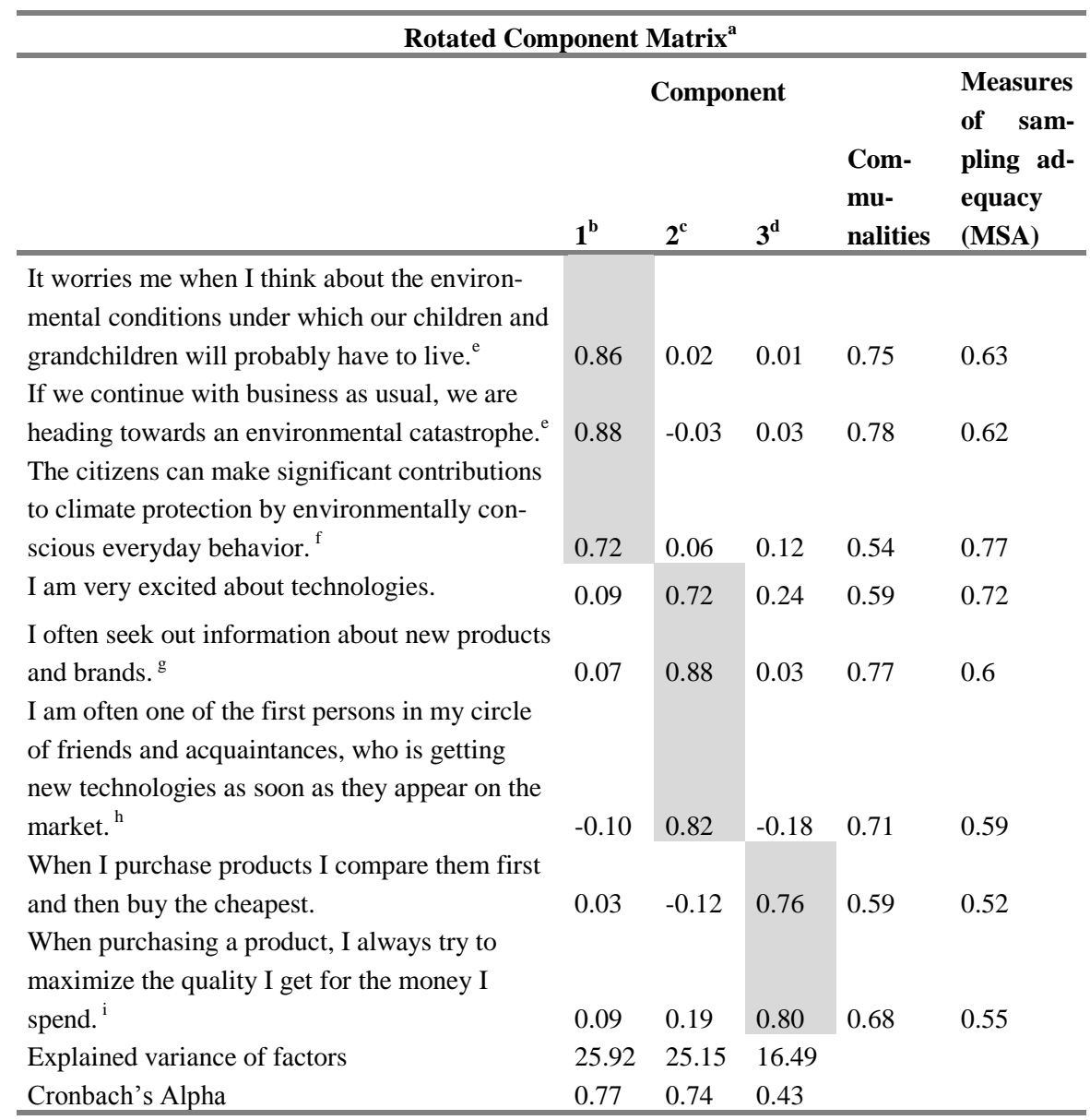

Extraction Method: Principal Component Analysis. Rotation Method: Varimax with Kaiser normalization.
a. Rotation converged in 4 iterations.
e. cf. Kuckartz et al. (2006)
b. Factor 1: Environmental awareness
f. cf. SINUS (2012)
c. Factor 2: Innovativeness
g. cf. Manning et al. (1995)
d. Factor 3: Price sensitivity
h. cf. Parasuraman (2000)
i. cf. Lichtenstein et al. (1993) 
Table a.2 Adjusted significance levels concerning differences of the samples' levels of environmental sensitivity, innovativeness and price sensitivity

\begin{tabular}{|c|c|c|c|c|}
\hline \multicolumn{2}{|l|}{ Pairwise comparisons } & \multicolumn{3}{|c|}{ Adjusted significance levels } \\
\hline Sample 1 & Sample 2 & $\begin{array}{l}\text { Environ- } \\
\text { mental } \\
\text { sensiti- } \\
\text { vity }\end{array}$ & $\begin{array}{l}\text { Innova- } \\
\text { tive-ness }\end{array}$ & $\begin{array}{l}\text { Price } \\
\text { sensi- } \\
\text { tivity }\end{array}$ \\
\hline E-scooter users & Persons interested in EV & n.s. & n.s. & $*$ \\
\hline E- scooter users & $\begin{array}{l}\text { Persons interested in smart } \\
\text { home technologies }\end{array}$ & n.s. & n.s. & $* *$ \\
\hline E- scooter users & Private EV customers & n.s. & n.s. & n.s. \\
\hline E- scooter users & LPG and CNG users & n.s. & n.s. & $* *$ \\
\hline E- scooter users & EV company car users & $* *$ & n.s. & n.s. \\
\hline Persons interested in EV & $\begin{array}{l}\text { Persons interested in smart } \\
\text { home technologies }\end{array}$ & n.s. & $* * *$ & n.s. \\
\hline Persons interested in EV & Private EV customers & n.s. & n.s. & $\circ$ \\
\hline Persons interested in EV & LPG and CNG users & n.s. & $* * *$ & n.s. \\
\hline Persons interested in EV & EV company car users & $* * *$ & n.s. & n.s. \\
\hline $\begin{array}{l}\text { Persons interested in smart } \\
\text { home technologies }\end{array}$ & Private EV customers & n.s. & n.s. & $*$ \\
\hline $\begin{array}{l}\text { Persons interested in smart } \\
\text { home technologies }\end{array}$ & LPG and CNG users & n.s. & n.s. & n.s. \\
\hline $\begin{array}{l}\text { Persons interested in smart } \\
\text { home technologies }\end{array}$ & EV company car users & $* * *$ & $*$ & n.s. \\
\hline Private EV customers & LPG and CNG users & n.s. & n.s. & $*$ \\
\hline Private EV customers & EV company car users & n.s. & n.s. & n.s. \\
\hline LPG and CNG users & EV company car users & $\circ$ & $* *$ & n.s. \\
\hline
\end{tabular}

Each row tests the null hypothesis that the Sample 1 and the Sample 2 distributions are the same. Asymptotic significance (2-sided tests) are displayed.

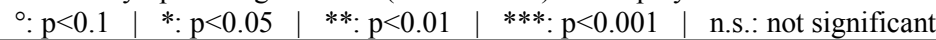


Table a.3 Variables in the equaton of model $P_{c}$

\begin{tabular}{|c|c|c|c|c|c|c|c|c|}
\hline & $\begin{array}{l}\text { Regression } \\
\text { coefficients } \\
\text { B }\end{array}$ & $\begin{array}{l}\text { Standard } \\
\text { errors } \\
\text { S.E. }\end{array}$ & Wald & df & Sig. & $\operatorname{Exp}(B)$ & $\begin{array}{l}95 \% \text { C.I. for } \\
\text { EXP(B) Up- } \\
\text { per value }\end{array}$ & $\begin{array}{l}\text { 95\% C.I. for } \\
\text { EXP(B) } \\
\text { Lower value }\end{array}$ \\
\hline$x_{c 1}$ & 0.691 & 0.369 & 3.504 & 1 & 0.061 & 1.996 & 0.968 & 4.117 \\
\hline$x_{c 2}$ & 2.079 & 0.850 & $\begin{array}{l}5.982 \\
4.709\end{array}$ & $\begin{array}{l}1 \\
2\end{array}$ & $\begin{array}{l}0.014 \\
0.095^{9}\end{array}$ & 7.993 & 1.511 & 42.276 \\
\hline$x_{c 3}$ & -0.349 & 0.425 & 0.674 & 1 & 0.412 & 0.706 & 0.307 & 1.622 \\
\hline$x_{c 4}$ & -0.970 & 0.448 & $\begin{array}{l}4.682 \\
8.701\end{array}$ & $\begin{array}{l}1 \\
2\end{array}$ & $\begin{array}{l}0.030 \\
0.013^{10}\end{array}$ & 0.379 & 0.158 & 0.913 \\
\hline$x_{c 5}$ & -0.706 & 0.454 & 2.426 & 1 & 0.119 & 0.493 & 0.203 & 1.200 \\
\hline$x_{c 6}$ & 0.600 & 0.457 & $\begin{array}{l}1.725 \\
7.244\end{array}$ & $\begin{array}{l}1 \\
2\end{array}$ & $\begin{array}{l}0.189 \\
0.027^{11}\end{array}$ & 1.822 & 0.744 & 4.458 \\
\hline$x_{c 7}$ & 0.097 & 0.490 & 0.039 & 1 & 0.843 & 1.102 & 0.422 & 2.878 \\
\hline$x_{c 8}$ & 2.062 & 0.787 & 6.868 & 1 & 0.009 & 7.864 & 1.682 & 36.773 \\
\hline$x_{c 9}$ & 0.649 & 0.415 & 2.451 & 1 & 0.117 & 1.914 & 0.849 & 4.316 \\
\hline$x_{c 10}$ & 0.587 & 0.240 & 6.001 & 1 & 0.014 & 1.799 & 1.125 & 2.878 \\
\hline Constant & -1.567 & 0.626 & 6.256 & 1 & 0.012 & 0.209 & & \\
\hline
\end{tabular}

Table a.4 Variables in the equaton of model $P_{a}$

\begin{tabular}{|c|c|c|c|c|c|c|c|}
\hline & $\begin{array}{l}\text { Regression } \\
\text { coefficients } \\
\text { B }\end{array}$ & $\begin{array}{l}\text { s Standard er- } \\
\text { rors S.E. }\end{array}$ & Wald df & Sig. & $\operatorname{Exp}(B)$ & $\begin{array}{l}95 \% \text { C.I. for } \\
\text { EXP(B) Lower } \\
\text { value }\end{array}$ & $\begin{array}{l}95 \% \text { C.I. for } \\
\text { EXP(B) Upper } \\
\text { value }\end{array}$ \\
\hline$x_{a 1}$ & 1.560 & 0.506 & $9.504 \quad 1$ & 0.002 & 4.759 & 1.765 & 12.831 \\
\hline$x_{a 2}$ & 0.684 & 0.437 & $2.444 \quad 1$ & 0.118 & 1.981 & 0.841 & 4.669 \\
\hline$x_{a 3}$ & 0.555 & 0.328 & $2.868 \quad 1$ & 0.090 & 1.742 & 0.916 & 3.313 \\
\hline Constant & 0.786 & 0.355 & $4.907 \quad 1$ & 0.027 & 2.195 & & \\
\hline
\end{tabular}

\footnotetext{
${ }^{9}$ Reference category for dichotomized variables $x_{c 3}$ and $x_{c 4}$ : Respondent has experienced EV during several trips.

${ }^{10}$ Reference category for dichotomized variables $x_{c 5}$ and $x_{c 6}$ : Respondent did not want to provide information about the households' net income.

${ }^{11}$ Reference category for dichotomized variables $x_{c 7}$ and $x_{c 8}$ : Car usage frequency: (Almost) daily.
} 


\section{Author Biographies}

Axel Ensslen is research associate at the French-German Institute for Environmental Research and member of the research group "Transport and Energy" at the Chair of Energy Economics since 2011. He studied industrial engineering at the Karlsruhe Institute of Technology (KIT), Germany and the Ecole Nationale Supérieure des Mines de Nancy (ENSMN), France. His research activities focus on socio-economic aspects of electric mobility.

Alexandra-Gwyn Paetz is a PhD-candidate at the Chair of Energy Economics at KIT. Her main research activities focus on new technologies in the electricity sector, such as smart grids, smart homes and electric vehicles. In 2007 she graduated in business economics at the Ludwig-Maximilians-University Munich. Today she works as executive assistant to the President of KIT.

Sonja Babrowski works since 2011 as a research associate at the Chair of Energy Economics of the Institute for Industrial Production (IIP) of KIT. In 2010 she graduated in industrial engineering at KIT. Her main area of research is energy system modeling with a focus on electric vehicles and electricity storage systems.

Patrick Jochem is since 2009 leader of the research group "Transport and Energy" at the chair of energy economics at KIT. Since 2012 he is senior researcher at the Karlsruhe Service Research Institute. In 2009 he received his $\mathrm{PhD}$ in transport economics from Karlsruhe University. He studied economics at the universities in Bayreuth, Mannheim and Heidelberg, Germany. His research interests are in the fields of electric mobility and ecological economics.

Wolf Fichtner is Director of the Institute for Industrial Production and the French-German Institute for Environmental Research. He is professor and holder of the Chair of Energy Economics at KIT. His main areas of research are Energy System Modelling and the Techno-economic Analysis of Energy Technologies. 


\section{Working Paper Series in Production and Energy}

recent issues

No. 1 Alexandra-Gwyn Paetz, Lisa Landzettel, Patrick Jochem, Wolf Fichtner: Eine netnografische Analyse der Nutzererfahrungen mit E-Rollern

No. 2 Felix Teufel, Michael Miller, Massimo Genoese, Wolf Fichtner: Review of System Dynamics models for electricity market simulations

No. 3 Patrick Jochem, Thomas Kaschub, Wolf Fichtner:

How to integrate electric vehicles in the future energy system?

No. 4 Sven Killinger, Kai Mainzer, Russell McKenna, Niklas Kreifels, Wolf Fichtner

A regional simulation and optimisation of renewable energy supply from wind and photovoltaics with respect to three key energy-political objectives

No. 5 Kathrin Dudenhöffer, Rahul Arora, Alizée Diverrez, Axel Ensslen, Patrick Jochem, Jasmin Tücking

Potentials for Electric Vehicles in France, Germany, and India

No. 6 Russell McKenna, Carsten Herbes, Wolf Fichtner:

Energieautarkie: Definitionen, Für-bzw. Gegenargumente, und entstehende Forschungsbedarfe

No. 7 Tobias Jäger, Russell McKenna, Wolf Fichtner:

Onshore wind energy in Baden-Württemberg: a bottom-up economic assessment of the socio-technical potential

No. 8 Axel Ensslen, Alexandra-Gwyn Paetz, Sonja Babrowski, Patrick Jochem, Wolf Fichtner:

On the road to an electric mobility mass market - How can early adopters be characterized?

The responsibility for the contents of the working papers rests with the author, not the institute. Since working papers are of preliminary nature, it may be useful to contact the author of a particular working paper about results or caveats before referring to, or quoting, a paper. Any comments on working papers should be sent directly to the author. 


\section{Impressum}

Karlsruher Institut für Technologie

Institut für Industriebetriebslehre und Industrielle Produktion (IIP) Deutsch-Französisches Institut für Umweltforschung (DFIU)

Hertzstr. 16

D-76187 Karlsruhe

KIT - Universität des Landes Baden-Württemberg und

nationales Forschungszentrum in der Helmholtz-Gemeinschaft

Working Paper Series in Production and Energy

No. 8, May 2015

ISSN 2196-7296 